Jurnal

\title{
Polymorphysm of $\mathrm{UCP}_{2}$ and $\mathrm{H}_{2} \mathrm{O}_{2}$ concentration to the CEC Level Variations As Predictors of Endothelial Activation In Stroke
}

\author{
M.Nur FAFA, Dianggan Sargowo, Achdiat Agoes, Wiwit Nurwidyaningtyas
}

FK.OR Universitas Negeri Malang

${ }^{2}$ Departemen Kardiologi dan

Kedokteran FKUB / RSSA Malang

${ }^{3}$ Departemen Neurologi FKUB / RSSA

Malang

${ }^{4}$ STIKES Kendedes Malang
Research Background. Stroke as brain vascular disorder that can be ruptured vascular commonly referred to as a bleeding stroke or ischemic stroke may be due to cerebral arterial thrombosis as a final impact the progression of atherosclerosis, especially in the area of branching blood vessels. Atherogenesis related to endothelial dysfunction as a consequence shear stress exposure leads endothelial cells undergo premature senescence and activation of endothelial than occur endothelial detachment from the basement membrane as a circulating endothelial cells (CEC). Mechanism shears stress on endothelial activation can not be separated from the increased production of hydrogen peroxidase $(\mathrm{H} 2 \mathrm{O} 2)$, which will activate the PPAR- $\alpha$ then increase levels of free fatty acids are capable of modulating the uncoupling protein 2 (UCP 2) gene as a compensation for lowering of free fatty acids.

Reseach Methods and Results. Researchers used 40 subjects were classified into two categories on a range of healthy and sick, who then performed blood sampling edge for lipid profile analysis, CEC using flowcytometry, $\mathrm{H} 2 \mathrm{O} 2$ measurement with ELISA techniques and DNA isolation followed by PCR procedures with the Genomic DNA that has been extracted from blood samples amplified with the 5'-GCT GCT CAC AGG TCT GCC AC3'sebagai forward primer and 5'-AGG CGT CAG GAG ATG GAC CG-3'sebagai reverse primer (Sesti et al, 2003; Oktavianthi et al, 20 I2). Genotype $(-866) \mathrm{AA}$ is characterized by fragments of $363 \mathrm{bp}$ cutting results Mlu I sites, whereas genotypes (-866) GG marked on fragments of 295 bp and 68 bp. The equipment used was a thermal cycler (Gene Amp ${ }^{\circledR}$ PCR System 9700 [Applied Biosystems, Foster City, CA, USA]). Results showed that

Conclusion. CEC in the group sick 3 times higher than the healthy group as well as the levels of $\mathrm{H} 2 \mathrm{O} 2$, but the two groups are not found polymorfism in both groups. Similarly, from the analysis of UCP2 gene allele frequencies between groups of stroke was not significantly different from the control group, this means yet certain UCP2 gene predispose and contribute to the pathogenesis of stroke.

(J Kardiol Indones. 20।4;35:255-62) 
Jurnal

Kardiologi Indonesia

J Kardiol Indones. 2014;35:255-62

ISSN $0126 / 3773$

\title{
Polimorfisme Gen UCP 2 Dan Kadar $\mathrm{H}_{2} \mathrm{O}_{2}$ Terhadap Variasi CEC Sebagai Prediktor Aktivasi Endotel Pada Pasien Stroke
}

\author{
M.Nur FAFA, Dianggan Sargowo, Achdiat Agoes, Wiwit Nurwidyaningtyas
}

\begin{abstract}
Latarbelakang. Stroke merupakan salah satu bentuk gangguan vaskuler otak yang dapat berupa ruptur vaskuler yang umum disebut sebagai bleeding stoke atau dapat berupa stroke iskemik akibat trombosis arteri serebral sebagai dampak akhir progresi aterosklerosis terutama pada area percabangan pembuluh darah. Proses aterogenesis tidak lepas dari disfungsi endotel akibat paparan shear stress yang menyebabkan sel endotel mengalami premature senescence dan terjadi aktivasi endotel yang diikuti proses pelepasan endotel (endothelial detachment) dari membran basalis dalam bentuk circulating endothelial cells (CEC). Mekanisme shears stress pada aktivasi endotel tidak lepas dari peningkatan produksi hidrogen peroxidase $(\mathrm{H} 2 \mathrm{O} 2)$ yang akan mengaktivasi PPAR- $\alpha$ yang kemudian akan meningkatkan kadar asam lemak bebas yang mampu memodulasi uncoupling protein 2 (UCP 2) gene sebagai bentuk kompensasi untuk menurunkan asam lemak bebas.

Tujuan. Penelitian ini ditujukan untuk mengetahui kadar $\mathrm{H} 2 \mathrm{O} 2$, mutasi gen UCP2 danlevel CEC didalam darah pasien stroke dan kelompok kontrol sehat. Selanjutnya akan dilihat keterikatan antara kadar H2O2 dan mutasi gen UCP2 terhadap level CEC pada seluruh sampel penelitian.

Metode dan Hasil Penelitian. Peneliti menggunakan 40 subyek yang dikelompokkan menjadi 2 kategori pada rentang sehat dan sakit, yang kemudian dilakukan pengambilan darah tepi untuk dilakukan analisa lipid profile, CEC dengan menggunakan flowcytometry, pengukuran $\mathrm{H} 2 \mathrm{O} 2$ dengan tehnik ELISA dan isolasi DNA dan dilanjutkan dengan prosedur PCR dengan Genomic DNA yang telah diekstraksi dari sampel darah diamplifikasi dengan 5'-CAC GCT GCT TCT GCC AGG AC-3'sebagai forward primer dan 5'-AGG CGT CAG GAG ATG GAC CG-3'sebagai reverse primer (Sesti et al, 2003; Oktavianthi et al, 2012). Genotipe (-866)AA ditandai oleh fragmen sebesar 363 bp hasil pemotongan situs Mlu1, sedangkan genotipe (-866)GG ditandai pada fragmen 295 bp dan 68 bp. Alat yang dipakai adalah thermal cycler (Gene Amp ${ }^{\circledR}$ PCR System 9700 [Applied Biosystem, Foster City, CA, USA]). Hasil menunjukkan bahwa

Kesimpulan. CEC pada kelompok sakit 3 kali lebih tinggi dibandingkan dengan kelompok sehat demikian juga dengan kadar $\mathrm{H} 2 \mathrm{O} 2$, namun pada kedua kelompok tidak ditemukan polymorfism pada kedua kelompok. Demikian pula dari analisa frekuensi alel gen UCP2 antara kelompok stroke tidak berbeda nyata dengan kelompok kontrol, ini berarti gen UCP2 belum bisa dipastikan menjadi faktor predisposisi dan berkontribusi pada patogenesis stroke
\end{abstract}

(J Kardiol Indones. 2014;35:255-62)

Kata kunci: UCP2, H2O2, CEC, aktivasi endotel

\footnotetext{
Alamat Korespondensi

Dr. Wiwit Nurwidyaningtyas, STIKES Kendedes Malang

E-mail :wiwit_nurwidyaningtyas@yahoo.com
} 


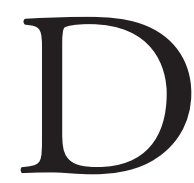
elapan puluh tiga persen dari seluruh kejadian stroke berupa stroke iskemik dengan proporsi $51 \%$ disebabkan oleh trombosis arteri serebral akibat progresi aterosklerosis. ${ }^{1}$

Menurut Yu et.al (2002), aterosklerosis sendiri merupakan implikasi formasi radikal bebas oleh peroksidasi lipid, meskipun dalam kondisi fisiologi radikal bebas seperti $\mathrm{H} 2 \mathrm{O} 2$ penting untuk fungsi biologis namun $\mathrm{H} 2 \mathrm{O} 2$ sangat reaktif dan tidak menyerang sasaran spesifik, sehingga ia juga akan menyerang asam lemak tidak jenuh ganda dari membran sel, organel sel, atau DNA yang dapat menyebabkan kerusakan struktur dan fungsi sel ${ }^{3}$ dan berpengaruh terhadap proses transkripsi dan translasi DNA ${ }^{4}$. $\mathrm{H} 2 \mathrm{O} 2$ juga mampu menembus sel endotel dan memodulasi aktivitas efek downstream termasuk menyebabkan phosporilasi protease dan faktor transkripsi (NFkB) yang menyebabkan aktivasi sel endotel. ${ }^{5}$

Selama proses respirasi seluler di mitokondria, O2 berperan dalam pembentukan adenosine trifosfat(ATP), akan tetapi sebagian $\mathrm{O} 2$ akan tereduksi membentuk superoksid, $\mathrm{O}^{-}$yang reaktif. Akibat rangsangan $\mathrm{NaD}(\mathrm{P}) \mathrm{H}$ oksidase yang meningkat pada pembuluh darah yang menua ${ }^{6}$ akan diproduksi Superoksida (O2-) yang mampu merangsang eNOS untuk memproduksi NO, tetapi hal tersebut akan diikuti pembentukan peroxynitrite (ONOO-) yang justru akan menghambat ketersediaan NO dan kerja antioksidan Manganese Superoksida Dismutase (MnSOD) didalam plasma yang berperan dalam mengubah Radikal Superoksida (O2- ) menjadi $\mathrm{H} 2 \mathrm{O} 2$ yang dapat meningkatkan permeabilitas endotel 7,8,9,10. Peroxynitrit (ONOO-) juga merupakan mediator penting dari peroksidasi lemak termasuk oksidasi LDL dan proses nitrasi protein yang berujung pada aterogenesis. ${ }^{8}$ Produksi O2-yang meningkat tampaknya akan mengikis reaktivitas dari endothelium dependent nitrovasodilator di dinding aorta dan berakibat berkurangnya daya untuk relaksasi ${ }^{9}$ dan penurunan $\mathrm{NO}$ akan menginisiasi mekanisme stress oksidatif. ${ }^{6}$

CEC digunakan sebagai indikator patologis injuri vaskuler. Aktifitas ini selalu mengacu pada adanya oksidatif stress dengan dibentuknya hydrogen peroxide ( $\mathrm{H} 2 \mathrm{O} 2)$ yang juga mampu menembus sel endotel dan memodulasi aktivitas efek downstream termasuk menyebabkan phosporilasi protease dan faktor transkripsi (NFkB) yang menyebabkan aktivitas sel endotel. ${ }^{5}$
$\mathrm{H} 2 \mathrm{O} 2$ yang tinggi akan meningkatkan Aktivitas PPAR-alfa akan menghambat diferensiasi makrofag menjadi foam cells, meningkatkan konsentrasi FFAs ${ }^{11}$, dan meningkatkan pembentukan Uncoupling Protein 2 (UCP2) yang merupakan suatu protein transmembran penghambat gradasi proton pada proses fosforilasi oksidatif 12 dan berfungsi menghambat migrasi transendothelial, mengurangi monosit / makrofag yang rolling pada plak ateroma dan terutama mengurangi ukuran plak pada kondisi aterogenik. ${ }^{11}$ Overekspresi gen UCP2 pada pembuluh darah akan mengurangi produksi ROS, meningkatkan modulasi ekspresi gen adiponectin, dan berpengaruh terhadap level circulating adiponektin. ${ }^{13}$ Adiponektin berperan sebagai antiinflamasi pada aterosklerosis. ${ }^{14,15}$ Defisiensi adiponektin menyebabkan intoleransi glukosa dan dislipidemia yang menyebabkan injuri endotel dan aterosklerosis. ${ }^{16}$

Polimorfisme nukleotida tunggal (SNP) -866G>A dari UCP2 berhubungan secara signifikan dengan gejala aterosklerosis arteri karotis yang pada wanita ${ }_{17}$ dan Sistem karotis secara fisiologis mensuplai area 2/3 bagian depan serebrum termasuk sebagian besar ganglia basalis dan capsula interna. ${ }^{18}$ Jika sistem karotis mengalami aterosklerosis maka bisa dipastikan sangat berhubungan dengan patomekanisme stroke iskemik yang menyumbang angka besar pada morbiditas stroke. Namun polimorfisme akibat mutasi Gen UCP2 pada aterosklerosis belum diketahui dengan pasti, diduga labelling enzim PARP pada DNA yang teroksidasi menyebabkan kerusakan endotel sebagai salah satu penyebab ateroskelrosis. ${ }^{12}$

\section{Metode}

\section{Pasien}

Keseluruhan sampel yang digunakan adalah 40 orang dengan jenis kelamin laki-laki untuk menghindari pengaruh menstruasi terhadap kadar CEC sebagai confounding factor, kelompok ini kemudian dibagi menjadi dua kategori dengan.

1. Kriteria responden kelompok kontrol sehat adalah:

Vital sign normal, terdiri dari $:^{19}$

a. Suhu tubuh $36,5^{0}-37,5^{\circ}$ Celcius

b. Denyut nadi $60-100 \mathrm{x} /$ menit

c. Tekanan darah $120 / 80 \mathrm{mmHg}$

d. Laju nafas $14-20 x /$ menit 
Jurnal Kardiologi Indonesia

2. Kriteria responden kelompok sakitadalah : Pasien stroke iskemik yang saat penelitian mendapatkan perawatan medis di rumah sakit sejumlah 20 orang pasien, dengan rentang usia antara 40-60 tahun.

\section{Prosedur studi}

Setelah melakukan validasi data dengan pengisian kuesioner biodata pasien dan data pendukung yang meliputi usia dan pemeriksaan vital sign serta $\mathrm{BB} / \mathrm{TB}$ maka dilakukan pengambilan darah tepi kemudian dilabel sesuai kriteria kelompok responden untuk kemudian dilakukan analisa lipid profile, CEC dengan menggunakan flowcytometry, pengukuran $\mathrm{H} 2 \mathrm{O} 2$ dengan tehnik ELISA dan isolasi DNA dan dilanjutkan dengan prosedur PCR untuk penentuan polimorfisme gen UCP 2.

\section{a. Metode pengukuran $\mathrm{H} 2 \mathrm{O} 2$}

Pengukuran kadar $\mathrm{H} 2 \mathrm{O} 2$ menggunakan metode Colorimetric Hidrogen Peroxide Kit (Assay Design).

Dengan langkah-langkah sebagai berikut (lampiran 2):

1. Larutan standart dibuat dengan melarutkan $34 \mu \mathrm{l}$ stok Hydrogen Peroxide Standart dengan $966 \mu \mathrm{l}$ diluent dan disebut sebagai larutan standart I.

2. Larutan standart II dibuat dengan melarutkan $500 \mu \mathrm{l}$ larutan standart I dengan $500 \mu \mathrm{l}$ diluent. Dibuat hingga larutan standart 6 dengan cara yang sama.

3. Kemudian dimasukkan $50 \mu$ l diluent pada well 1 sebagai larutan blanko, $50 \mu$ larutan standart 1 hingga IV ke dalam well selanjutnya. Masingmasing larutan sampel diambil $50 \mu \mathrm{l}$ dimasukkan ke dalam well selanjutnya.

4. Selanjutnya semua well ditambahkan $100 \mu \mathrm{l}$ Color Reagent dan dipipeting selama 1 detik. Inkubasi dilakukan pada suhu ruang selama 30 menit.

5. Selanjutnya dibaca pada panjang gelombang 560 nm dengan Elisa Reader.

\section{b. Metode Isolasi Gen UCP2}

Protein UCP2 disandi oleh gen yang terpetakan pada kromosom 11q 13. Sebelum mengisolasi gen tersebut langkah pertama yang dilakukan adalah mengisolasi DNA dari darah

\section{c. Prosedur Isolasi DNA}

Isolasi DNA menggunakan Blood DNA Extraction Kit dimana prosedur isolasinya sebagai berikut (lampiran
3):

1. $200 \mu \mathrm{L}$ buffer BB dicampurkan dalam $200 \mu \mathrm{L}$ darah pada microcentrifuge tube lalu divortex.

2. Tambahkan $200 \mu \mathrm{L}$ proteinase $\mathrm{K}$ secepatnya lalu di inkubasi pada suhu $65^{\circ} \mathrm{C}$ selama 10 menit

3. Tambahkan $200 \mu \mathrm{L}$ absolute ethanol ke dalam tabung sentrifugasi tersebut. Tabung sentrifugasi diinkubasi selama 1 menit dengan kecepatan $5000 \mathrm{~g}$

4. Supernatan dari hasil sentrifugasi dibuang. Tambahkan $500 \mu \mathrm{L}$ wash buffer1 lalu disentrifugasi pada kecepatan $5000 \mathrm{~g}$ selama 1 menit

5. Supernatan dari hasil sentrifugasi dibuang. Tambahkan $500 \mu \mathrm{L}$ wash buffer2 lalu disentrifugasi pada kecepatan $5000 \mathrm{~g}$ selama 1 menit

6. Supernatan dari hasil sentrifugasi dibuang. Tambahkan $100 \mu \mathrm{L}$ elution buffer, biarkan selama 2 menit. lalu disentrifugasi pada kecepatan $5000 \mathrm{~g}$ selama 1 menit untuk mendapatkan DNA. simpan DNA pada suhu $4^{\circ} \mathrm{C}$ atau $-20^{\circ} \mathrm{C}$

\section{d. Prosedur PCR-RFLP}

Genomic DNA yang telah diekstraksi dari sampel darah diamplifikasi dengan 5'-CAC GCT GCT TCT GCC AGG AC-3'sebagai forward primer dan 5'-AGG CGT CAG GAG ATG GAC CG-3'sebagai reverse primer (Sesti et al, 2003; Oktavianthi et al, 2012). Genotipe (-866)AA ditandai oleh fragmen sebesar 363 bp hasil pemotongan situs Mlu1, sedangkan genotipe (-866)GG ditandai pada fragmen 295 bp dan 68 bp.

Alat yang dipakai adalah thermal cycler (Gene Amp ${ }^{\circledR}$ PCR System 9700 [Applied Biosystem, Foster City, $C A, U S A]$ ), tabung PCR, mikropipet dan white tip.

Bahan dimasukkan ke dalam tabung PCR, selanjutnya diletakkan di dalam thermal cycler. Kondisi amplifikasi untuk primer varian UCP2 adalah pada suhu $58^{\circ} \mathrm{C}$.amplifikasi keseluruhan adalah 35 siklus (annealing) yang diikuti perpanjangan terakhir 5 menit (GeneAmp 9700 PCR, Applied Biosystems, USA) (Hlubocka et al.,2009). Setelah proses amplifikasi selesai, kemudian dilakukan elektroforesis gel untuk melihat produk PCR yang dikehendaki.

\section{d. Restriction Fragment Leghth Polymorphisms (RFLP)}

Bahan yang dipakai produk PCR adalah enzim restriksi Mlu 1(NEB, Ipswich, MA, USA) untuk polimorfisme gen UCP2varian $G(-866) A$. Alat yang dipakai adalah inkubator, mikropipet dan white tip. Untuk 
penggunaan enzim restriksi Mlu1 diberikan sebanyak $5 \mu \mathrm{l}$ untuk setiap tabung dan dilakukan inkubasi minimal selama 2 jam dalam suhu $37^{\circ} \mathrm{C}$, setiap reaksi memproduksi fragmen 363 bp. Fragmen ini adalah kemudian dipotong oleh Mlu1 dan menghasilkan fragmen-fragmen untuk alel Genotipe (-866)AA ditandai oleh fragmen sebesar 363 bp, sedangkan genotipe (-866) GG ditandai pada fragmen $295 \mathrm{bp}$ dan 68 bp, yang mana mengalami elektroforesis pada gel metaphoragarose dan divisualisasikan dengan etidium bromida. Setelah produk RFLP diperoleh kemudian dilakukan pembacaan hasil dengan menggunakan elektroforesis gel.

\section{e. Elektroforesis Gel}

Bahan yang dipakai adalah buffer TBE, agarosa, buffer loading 10x, produk PCR-RFLP dan ethidium bromide $10 \mathrm{mg} / \mathrm{ml}$. Alat yang dipakai adalah oven microwave, mikropipet, white tip, submerged horizontal electrophoresis (Wide Mini-Sub Cell GT Cell [BioRad, Hercules, CA, USA]) dan UV transilluminator (GelDoc-it Imaging System 3 UV Transilluminator [UVP, LLC Upland,CA,USA).

Agarosa dimasukkan ke dalam buffer TBE kemudian dilarutkan di dalam oven microwave. Selanjutnya suhu diturunkan sampai $50^{\circ} \mathrm{C}$ kemudian ditambahkan ethidium bromide. Kemudian dituangkan ke dalam gel casting platform dan gel comb dipindahkan. Kemudian gel casting platform diletakkan di dalam tangki perangkat elektroforesis gel. Buffer TBE ditambahkan hingga menutupi gel kira-kira setinggi $1 \mathrm{~mm}$. Sementara itu dimasukkan 10x buffer loading ke dalam sampel DNA, kemudian dimasukkan ke dalam sumuran dengan mikropipet. Ditambahkan DNA ladder (GeneRuler 100 bp DNA Ladder \#SM0371 dari Fermentas, Burlington, ON, Canada) untuk membantu proses pembacaan hasil. Powersupply dimatikan jika proses pemisahan fragmen DNA dirasa telah cukup. Selanjutnya dilakukan pengamatan dan pembuatan dokumentasi dengan bantuan $U V$ transilluminator (Ausubel et al,2002 dan Sudjadi,2008).

\section{f. Prosedur Pengukuran CEC}

1. siapkan tube $15 \mathrm{ml}$ kemudian isi dengan vicoll dan darah dengan perbandingan 1:1 yaitu $2 \mathrm{cc}$ vicoll dan 2 cc darah kemudian disentrifus selama 30 menit dengan kecepatan $1000 \mathrm{rpm}$

2. ambil bagian buffie coat dengan pipet dan letakkan di tube $15 \mathrm{ml}$ yang baru dan tambahkan PBS sampai menjadi $10 \mathrm{ml}$, disentrifus lagi selama 10 menit dengan kecepatan $100 \mathrm{rpm}$

3. supernatan dibuang dan ditambahkan PBS sampai menjadi $5 \mathrm{ml}$ dan disentrifuse selama 30 menit dengan kecepatan $1000 \mathrm{rpm}$

4. siapkan antibody CD146 PE dan CD 45 FITC dengan perbandingan $1 \mu$ antibody: $50 \mu \mathrm{PBS}$ lalu di vortex

5. setelah langkah 3 selesai supernatan dibuang.

6. Pellet ditambahkan antibody @25 $\mu$ l lalu didiamkan pada suhu ruangan selama 15-20 menit

7. Selanjutnya tambahkan PBS 200 $\mu$ l lalu dipipeting. Pindah ke dalam tabung flowcytometry untuk dianalisis

\section{Analisa statistik}

Data kuantitatif yang diperoleh dianalisa menggunakan software SPSS.19 untuk mengetahui kadar $\mathrm{H} 2 \mathrm{O} 2$, mutasi gen UCP2 dan level CEC didalam darah pasien stroke dan kelompok kontrol sehat. Selanjutnya akan dilihat keterikatan antara kadar $\mathrm{H} 2 \mathrm{O} 2$ dan mutasi gen UCP2 terhadap level CEC pada seluruh sampel penelitian dengan menggunakan uji Anova untuk mengetahui tingkat perbedaan masingmasing variabel pada kelompok kontrol dan kelompok sakit dan dilanjutkan dengan uji korelasi regresi utuk mengetahui tingkat keeratan hubungan masing-masing variabel pada seluruh sampel penelitian. Signifikasi ditentukan jika nilai $\mathrm{p}<0.05$

\section{Hasil penelitian}

Dari hasil analisa H2O2, CEC, Sistolic Blood presure (SBP) pada kelompok sakit cenderung menunjukkan hasil yang lebih tinggi dibandingkan dengan kelompok sehat.

Sedangkan pada analisa genotif UCP2 menunjukkan bahwa 75\% kelompok sakit menunjukkan genotif GG sedangkan pada kelompok sehat $80 \%$, dan untuk getif GA pada kelompok sehat 20\% sedangkan pada

Tabel 1. Hasil Analisa pemeriksaan $\mathrm{H} 2 \mathrm{O} 2$ dan CEC, SBP dan genotif UCP2

\begin{tabular}{lcc}
\hline Parameter & Kelompok sehat & Kelompok sakit \\
\hline Rata-rata H2O2 & $115.99 \mu \mathrm{Mol}$ & $174.06 \mu \mathrm{Mol}$ \\
Rata-rata CEC & 0.02 & 3.87 \\
Rata-rata SBP & $120.5 \mathrm{mmHg}$ & $130.5 \mathrm{mmHg}$ \\
UCP2 genotif : & & \\
GG $(\%)$ & $80 \%$ & $75 \%$ \\
GA $(\%)$ & $20 \%$ & $25 \%$ \\
AA $(\%)$ & $0 \%$ & $0 \%$ \\
\hline
\end{tabular}


kelompok sakit 25\%, dari analisa uji beda tidak didapatkan berbedaan yang signifikan pada kedua kelompok terhadap variasi genotif dengan p.value 0.715 (GG) dan p.value 0.527 (GA).

\section{Analisis Polimorfisme Gen UCP2 dengan PCR-RFLP}

Polimorfisme gen UCP2 ditunjukkan oleh variasi pada rentang DNA UCP2 yang meliputi situs polimorfik Mlu1 terletak pada posisi -866. Amplifikasi daerah tersebut dilakukan dengan metode PCR, menggunakan primer UCP2 dan berhasil dan bernilai positif dengan produk PCR berukuran 363 pb (Gambar 1.). Hal ini menunjukkan bahwa primer yang digunakan adalah benar dan sesuai dengan yang diharapkan.

Proporsi Hasil RFLP masing-masing individu memiliki 3 kemungkinan genotip, yaitu -866GG, -866GA, dan -866AA.

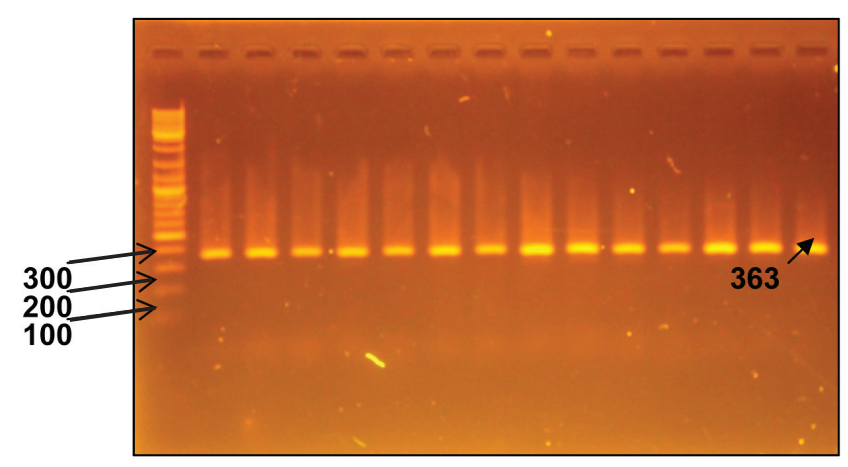

Gambar 1. Produk PCR (primer) dengan ukuran 363 bp setelah dielektroforesis dengan gel agarosa $2 \%$ selama 60 menit yang divisualisaikan dengan iluminator UV

$M \quad M_{1} M_{2} M_{3} M_{4} M_{5} M_{6} M_{7} M_{8} M_{9} M_{10} R_{1} R_{2} R_{3} R_{4}$

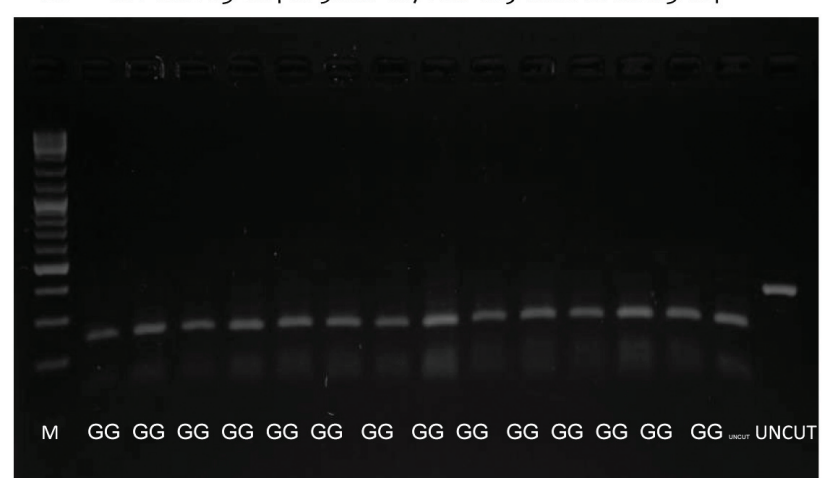

Gambar 2. Hasil elektroforesis produk PCR-RFLP DNA UCP2 kelompok sehat pada gel agarosa $2 \%$ selama 60 menit yang dideteksi dengan UV iluminator

\section{Analisis genotif dan fenotif UCP 2 kelompok pengamatan}

Dari gambaran di atas dapat disimpulkan bahwa tidak ada hubungan yang signifikan antara sub variabel dengan genotif UCP pada masing-masing kelompok, kecuali genotif kelompok sehatan dengan SBP dengan Tabel 2. Uji Korelasi sub Variabel Penelitian

\begin{tabular}{lccc}
\hline UJI KORELASI & $\mathrm{H} 2 \mathrm{O} 2$ & CEC & Sistolik \\
\hline Frekuensi Genotip_SEHAT & & & \\
Correlation Coefficient & -0.260 & -0.331 & -0.559 \\
Sig. (2-tailed) & 0.268 & 0.154 & 0.010 \\
& & & \\
Frekuensi Genotip_SAKIT & & & \\
Correlation Coefficient & -0.208 & 0.246 & -0.225 \\
Sig. (2-tailed) & 0.379 & 0.295 & 0.340 \\
\hline
\end{tabular}

Pada masing-masing kelompok pengamatan

p.value 0.010 .

\section{Diskusi}

Gen UCP2 merupakan famili mitokondrial transporter yang ekspresinya dikaitkan dengan metabolisme termasuk modulasi plasma free fatty acid. Diketahui bahwa -866 G dari UCP2 berhubungan dengan penurunan jaringan adiposit, penurunan aktifitas transkripsi dan peningkatan Body Mass Indeks (BMI). Sedangkan genotif VV, AA atau AV menunjukkan rendahnya energy expenditure, lower fat oxidation dan peningkatan exercise. Genotif I/D menujukkan penurunan BMI dan peningkatan energy expenditure. ${ }^{20}$ Distribusi genotip UCP2 pada populasi pengamatan penelitian ini menunjukkan bahwa pada kelompok stroke dan kontrol memperlihatkan pola penyebaran yang hampir sama dan tidak ada hubungan yang signifikan antara sub variabel dengan genotif UCP pada masing-masing kelompok, kecuali genotif kelompok sehatan dengan SBP dengan p.value 0.010. Hal ini menunjukkan bahwa ada faktor lain yang mempengaruhi ekpresi UCP2 seperti BMI, lingkar perut, onset CVA iskemik dan gamaran post CVA iskemik yang belum dilihat pada penelitian ini. Menurut Barbieri (2011) pada sistem neuronal UCP2 dominan terletak pada neuronal di regio sub-cortical yang berfungsi sebagai autokrin, endokrin dan regulator metabolit. Peningkatan ekspresi UCP2 pada sistem neuronal berhubungan dengan neuronal survival dan meminimalkan disfungsi otak post stroke, hal ini 
dikaitkan dengan fungsi UCP yang dapat menurunkan ROS yang mempunyai sifat neuronal exocytotoxic.

Maka kemungkinan pemilihan sampel untuk prosedur PCR dari UCP2 berkaitan dengan stroke perlu mempertimbangkan media jaringan atau sel neuron melalui studi in vivo.

Tingginya kadar $\mathrm{H} 2 \mathrm{O} 2$ dengan level CEC pada kelompok pasien stroke dan kelompok kontrol sehat tidak memiliki perbedaan yang signifikan $(\mathrm{p}>0,05)$. Rata-rata level CEC pada kelompok pasien stroke adalah 3,8705\% lebih tinggi dari kelompok kontrol sehat yaitu 0,0219\%. Level CEC yang rendah pada pasien stroke diduga karena saat pengambilan data pasien sedang mengalami proses pengobatan, sehingga terjadi remodeling dan regenerasi sel endotel

Mekanime lepasnya sel endotel dari dinding pembuluh darah merupakan proses yang kompleks dan dipengaruhi banyak faktor seperti injuri mekanik, rusaknya molekul adesi sel endotel/subendotel mupun lepasnya marik protein dan apoptosis seluler yang disebabkan penurunan fungsi sitoskleton. ${ }^{21}$ Oleh karena itu lepasnya endotel dari intima akan selalu diikuti oleh kerusakan vaskuler dan CEC jarang ditemui pada orang sehat yaitu kurang dari $5 \mathrm{sel} / \mathrm{ml}$. Sebagai sel yang terlepas, CEC menunjukkan jumlah sel endotel yang mengalami anoikis (detachment induce cell death program), meningkatnya jumlah CEC dalam plasma terjadi pada penyakit vaskuler dan diyakini sebagai refleksi kerusakan maupun stress endotel. ${ }^{21}$

\section{Kesimpulan}

Distribusi genotip UCP2 pada populasi pengamatan penelitian ini menunjukkan bahwa pada kelompok stroke dan kontrol memperlihatkan pola penyebaran yang hampir sama dan tidak ada hubungan yang signifikan antara sub variabel dengan genotif UCP pada masing-masing kelompok, kecuali genotif kelompok sehatan dengan SBP dengan p.value 0.010.

\section{Daftar pustaka}

1. Chan KL, Morin J, Veinot JP. 2009. Unusual cause of sudden death in a young patient with atrioventricular septal defect. Can J Cardiol.25(1):e19-e25.

2. Yu L, Haley S, Perret J, Harris M, Wilson J and Qian M. 2002. Free radical scavenging properties of wheat extracts. J Agric Food Chem.50: 1619-1624.
3. Halliwell, B., and J.M.C. Gutteridge. 1996. Free radicals in biology and medicine. Oxford University Press, Oxford.

4. Rice-Evans, C., Anthony, T.D. 1991. Techniques In Free Radical Research. Elsevier. P146-202

5. Rabelink, T. J. : Nat. Rev. Nephrol. 6, 404 - 414 (2010) Endothelial activation and circulating marker of endothelial activation in kidney disease.

6. Csiszar A, J Toth1, J Peti-Peterdi, Z Ungvari. 2007.The aging kidney: role of endothelial oxidative stress and inflammation. Acta Physiologica Hungarica. 94(1-2): 107-115

7. Van der Loo B, Labugger R, Skepper JN, Bachschmid M, Kilo J, Powell JM, Palacios-Callender M, Erusalimsky JD, Quaschning T, Malinski T, Gygi D, Ullrich V, Luscher TF. 2000. Enhanced peroxynitrite formation is associated with vascular aging. J Exp Med.192:1731-1744

8. Griendling, K. K. and G. A. FitzGerald (2003). "Oxidative stress and cardiovascular injury: Part II: animal and human studies.” Circulation 108(17): 2034-40.

9. Brandes, Ralf P. Ingrid Fleming. Rudi Busse. 2005. Endothelial aging. Cardiovascular Research. 66: 286-294. www.elsevier.com/ locate/cardiores. Downloaded on May, 28, 2013

10. Bernard I. Levy, Ernesto L. Schiffrin, Jean-Jacques Mourad, Denis Agostini, Eric Vicaut. 2008. Impaired Tissue Perfusion: A Pathology Common to Hypertension, Obesity, and Diabetes Mellitus. Circulation. 118:968-976

11. Ryu JW, Hong KH, Maeng JH, Kim JB, Ko J, Park JY, Lee KU, HongMK, Park SW, Kim YH, Han KH. 2004.Overexpression of uncoupling protein 2 in THP1 monocytes inhibits beta2 integrin-mediated firm adhesion andtransendothelial migration. Arterioscler Thromb Vasc Biol. 24:864-870.

12. Piqueras L. Sanz MJ. Perretti M. Morcillo E. Norling L. Mitchell JA. Li Y. Bishop-Bailey D. 2009. Activation of PPARbeta/ delta inhibits leukocyte recruitment, cell adhesion molecule expression, and chemokine release. J Leukoc Biol. 86(1):115122

13. Chevillotte E, Giralt M, Miroux B, Ricquier D, Villarroya F. 2007.Uncouplingprotein-2 controls adiponectin gene expression in adipose tissue throughthe modulation of reactive oxygen species production. Diabetes. 56:1042-1050

14. Ouchi N, Kihara S, Arita Y, Maeda K, Kuriyama H, Okamoto Y, Hotta K, Nishida M, Takahashi M, Nakamura T, Yamashita S, Funahashi T, Matsuzawa Y. 1999. Novel modulator for endothelial adhesion molecules: adipocytederived plasma protein adiponectin. Circulation.100:2473-2476

15. Ouchi, N. Terauchi, Y. Yamauchi, T. 2000. adiponectin, an adipocytederived plasm protein, inhibits enothelial NFkB signalig through a cAMP dependent pathway. Cirulation. 102: 1296-1301

16. Kubota, N., Terauchi, Y. and Yamauchi, T. 2002. Disruption of adiponectin causes insulin resistance and neointimal formation. 
J. Biol. Chem., 277:25863-6.

17. H. Oberkofler, B. Iglseder, K. Klein, J. Unger, M. Haltmayer, F. Krempler, B. Paulweber, W. Patsch , 2005, Associations of the UCP2 Gene Locus With Asymptomatic Carotid Atherosclerosis in Middle-Aged Women, Arterioscler Thromb Vasc Biol. 2005;25:604-610

18. Japardi, Iskandar, 2002 Japardi, 2002. Patofisiologi Stroke Infark Akibat Tromboemboli. http://library.usuac.id.

19. Lyrawati D (2009) Mitochondria powerhouse of disease: lecture for postgrad (S3) Fac. Med Brawijaya University. pdf (low res.) pdf mt-dis https://lyrawati.wordpress.com/molecular-biology/ on line

20. Michelangela Barbieri \& Virginia Boccardi \& Antonietta Esposito \& Michela Papa \& Francesco Vestini \& Maria Rosaria Rizzo \& Giuseppe Paolisso, 2011, A/ASP/VAL allele combination of IGF1R, IRS2, and UCP2 genes is associated with better metabolic profile, preserved energy expenditure parameters, and low mortality rate in longevity, AGE (2012) 34:235-245 DOI 10.1007/s11357-011-9210-z

21. Christoper J. Boos., 2006, Circulating endothelial cells in cardiovascular disease, Journal of American College of cardiology, Vol. 48, No.8, 2006 ISSN 0735-1097/06 